\title{
Diversity of Sub-Gingival Fluids Microbiota Compositions in Periodontitis and Rheumatoid Arthritis Patients: A Case- Control Study
}

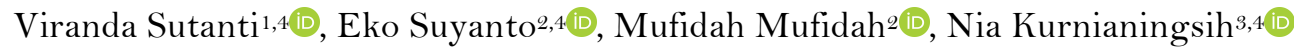

${ }^{1}$ Department of Oral Biology, Faculty of Dentistry, Brawijaya University, Malang, Indonesia.

${ }^{2}$ Department of Biology, Faculty of Mathematics and Natural Sciences, Brawijaya University, Malang, Indonesia.

${ }^{3}$ Department of Physiology, Faculty of Medicine, Brawijaya University, Malang, Indonesia.

${ }^{4}$ Research Center for Smart Molecules of Natural Genetic Resources, Brawijaya University, Malang, Indonesia.

Author to whom correspondence should be addressed: Eko Suyanto, Department of Biology, Faculty of Mathematics and Natural Sciences, Brawijaya University, Malang, Indonesia. Phone: +62 87863526834. E-mail: esuyanto31@,ub.ac.id.

Academic Editors: Alessandro Leite Cavalcanti and Wilton Wilney Nascimento Padilha

Received: 08 December 2019 / Accepted: 20 May 2020 / Published: 13 June 2020 How to cite this article: Sutanti V, Suyanto E, Mufidah M, Kurnianingsih N. Diversity of sub-gingival fluids microbiota
compositions in periodontitis and rheumatoid arthritis patients: a case-control study. Pesqui Bras Odontopediatria Clín
Integr. 2020; 20:e5437. https://doi.org/10.1590/pboci.2020.107

\begin{abstract}
Objective: To determine the diversity of microbiota in the sub-gingival fluids from periodontitis and rheumatoid arthritis (RA) patients and to know the relationship of microbiota abnormalities between periodontitis and RA. Material and Methods: Samples were collected from sub-gingival fluids of nine participants by swabbing technique. The participants were divided into 3 groups, namely the control (not periodontitis and RA), periodontitis, and RA. The total number of bacteria was calculated by using direct culture in serial dilution by applying the total plate count method. Isolation of microbiota was conducted by pour plates and incubated in an anaerobic jar. The bacterial diversity was performed by Simpson index and DNA Isolation. Results: There were differences in the concentration of sub-gingival fluids bacteria in the control group with the periodontitis and RA group. The microbiota composition profiles were different for each group. The bacterial isolate 4, 5 and 22 were found in all groups, while isolate 14 was assumed to be related to the metabolic pathway in microbiota abnormalities associated with disease progression. Conclusion: The Simpson index has a value $>0.61$ with high bacterial dominance; however, the diversity of microbiota is at a low level of diversity. We assumed that isolate 14 was associated with development of RA disease.
\end{abstract}

Keywords: Epidemiologic Studies; Periodontics; Periodontal Diseases; Arthritis, Rheumatoid. 


\section{Introduction}

Rheumatoid arthritis (RA) is characterized by inflammation in the joints that causes pain, swelling, and damage to bone tissue. It has a socially and psychologically big impact and even triggers stress that leads to death and disrupts economic productivity [1,2]. Treatment to cure or suppress RA disease has been using disease modifying rheumatoid arthritis drugs (DMRADs) with conventional first-line use of methotrexate [3]. Another group that is used is immune suppressants, corticosteroids, and chloroquine, which can cause side effects, namely hypersensitivity reactions, impaired liver, and kidney function, as well as suppress the hematopoietic system [4]. The use of bioactive compounds and smart molecules from natural ingredients opens up great opportunities in new treatments for saving and promising diseases in the future [5].

The genetic and environmental factors are very influential on the emergence of RA. Nevertheless, biomechanism is still being studied and analyzed until now. The existence of periodontitis is known to increase the risk of RA $[6,7]$. Another environmental factor that plays a role is the presence of microbiota abnormalities (dysbiosis) in the intestinal environment [8]. Human intestine is the part of body that mostly contains microbes. The large number of microbiota found in the human intestine has a role in the mechanism of biological regulation and physiology of the body; thus, microbiota abnormalities can increase the risk of infections that cause various diseases, one of them is RA $[8,9]$.

The influence of environmental factors is not fully understood until today. However, it is known that IgA anti-citrullinated protein antibody (ACPA) is detected before the appearance of RA. Besides that, periodontal pathogenic bacteria, Porphyromonas gingivalis, are reported to be associated with the development of RA due to these bacteria express peptidilarginin deiminase (PAD) associated with ACPA [10]. Furthermore, there is an increase of Lactobacillus salivarius in the intestines, teeth, and saliva in RA patients [8].

This study aimed to determine the diversity of the microbiota composition through Simpson diversity index in the sub-gingival fluids from periodontitis and rheumatoid arthritis (RA) patients. This research has potential to become basic data to reveal the other bacteria related to development of disease and be used in further research.

\section{Material and Methods}

Study Design

The study used a case-control study model. The study samples were divided into 3 groups, namely the control (CG, no periodontitis and RA), periodontitis (PG), and Rheumatoid Arthritis (RAG) group with 3 replications each of participants. Patients were recruited by using the consecutive sampling method after obtaining an explanation and signing informed consent. The inclusion criteria of patients were proven to have periodontitis and RA by medical records from the hospital, did not consume the antibiotics and did not consume yoghurt for the last 4 weeks and Indonesian citizenship proved by identity cards.

\section{Sample Collections and Bacterial Total Count}

The samples were obtained by swabbing the sub-gingival fluids of participants in control, periodontitis and RA group. A sterile paper point was inserted for 20 seconds then transferred to the brain heart infusion (BHI) broth media. The samples from each group were put in separate and sterile tubes [11,12] and stored at $4^{\circ} \mathrm{C}$ before use [13]. The total number of bacteria from the samples for each sub-gingival swab were determined by Total Plate Count (TPC) method in a serial dilution of $0.9 \% \mathrm{NaCl}$ using plate count agar (PCA) media and then incubated at $37^{\circ} \mathrm{C}$ for $48 \mathrm{~h}$. 


\section{Isolation of Sub-Gingival Fluids Microbiota}

A sub-gingival fluids sample from each of control, periodontitis and RA participants were analyzed by direct culture. The bacterial cells in sub-gingival fluids were isolated by serial dilution technique using peptone yeast extract glucose (PYG) media and it was incubated in anaerobic conditions at $37^{\circ} \mathrm{C}$ for $48-72 \mathrm{~h}$ [14]. The colonies of bacteria were purified by a four-way streak plate to obtain a pure colony. The characterization of isolates was carried out by morphological observations, including shape, configuration, elevation, optical characteristics, texture, color, and edges.

\section{Determination of Diversity Index}

Diversity index was calculated to determine the diversity of bacterial species in each group. The diversity index used in this study was the Simpson diversity index. The number of certain isolate found in each sample was counted. Besides that, the number of isolate that was found in each sample was also calculated. The data was calculated by using ID formula [15]. The Simpson diversity index ranged from 0 to 1 . The representations of the index values are as follows, 0.0-0.3: low dominance, high diversity; 0.3 1-0.6: moderate dominance, moderate diversity; and 0.61-1.0: high dominance, low diversity.

\section{Bacterial DNA Isolation}

Isolation of bacterial DNA followed Vural and Ozgun method with some modifications [16]. The bacterial cultures in LB broth media were centrifuged at $8,000 \mathrm{rpm}, 4^{\circ} \mathrm{C}$ for $5 \mathrm{~min}$. The pellets were added by 1 $\mathrm{mL}$ of lysis buffer and incubated $37^{\circ} \mathrm{C}$ for $1 \mathrm{~h}$. After that, the suspension was centrifuged at $10,000 \mathrm{rpm}, 4^{\circ} \mathrm{C}$ for $10 \mathrm{~min}$; then the pellets were added by PCI reagent for $1 \mathrm{x}$ volume and homogenized by vortex for 2 min then followed by centrifugation again at $10,000 \mathrm{rpm}, 4^{\circ} \mathrm{C}$ for $10 \mathrm{~min}$. The supernatant was transferred into a microtube and added with the absolute ethanol for $2.5 \mathrm{x}$ volume and incubated at $-20^{\circ} \mathrm{C}$ for $5 \mathrm{~min}$. Then, it was centrifuged again at $10,000 \mathrm{rpm}, 4^{\circ} \mathrm{C}$ for $10 \mathrm{~min}$. The pellets were washed by $70 \%$ ethanol and vortexed for 5 min. The centrifugation was performed at $10,000 \mathrm{rpm}, 4^{\circ} \mathrm{C}$ for $10 \mathrm{~min}$. The pellets were air-dried at room temperature for $15 \mathrm{~min}$. The pellets were added by $50 \mu \mathrm{L}$ of TE buffer $\mathrm{pH} 7.6$ and stored at $-20^{\circ} \mathrm{C}$. The DNA samples were analyzed by quantitative tests using Nano drop and qualitative tests using electrophoresis with $1 \%$ agarose gel at $100 \mathrm{~V}$ for $60 \mathrm{~min}$. The DNA bands in the gel were visualized using Gel-Doc system (Biostep gel documentation system).

\section{Data Analysis}

All data were captured into Microsoft Excel® to calculate the descriptive statistics, including Simpson diversity index, error bars, mean and standard deviation, and absolute and relative frequencies.

\section{Ethical Aspects}

This study was approved by the Health Research Ethics Commission (KEPK) Faculty of Medicine and Health Sciences UIN Maulana Malik Ibrahim, Malang, with ethical clearance No. 051/EC/KEPK-FKIK/2019. All participants were required to sign informed consent.

\section{Results}

The number of bacteria varied in a stable concentration range of $10^{5}$ for all samples based on this result. However, there was an increase in the number of bacteria in PG compared to RAG and CG (Figure 1). 
This showed that the bacterial community in the sub-gingival fluid of periodontitis patients has varying amounts and possible types of bacteria suspected to be anaerobic pathogenic bacteria.

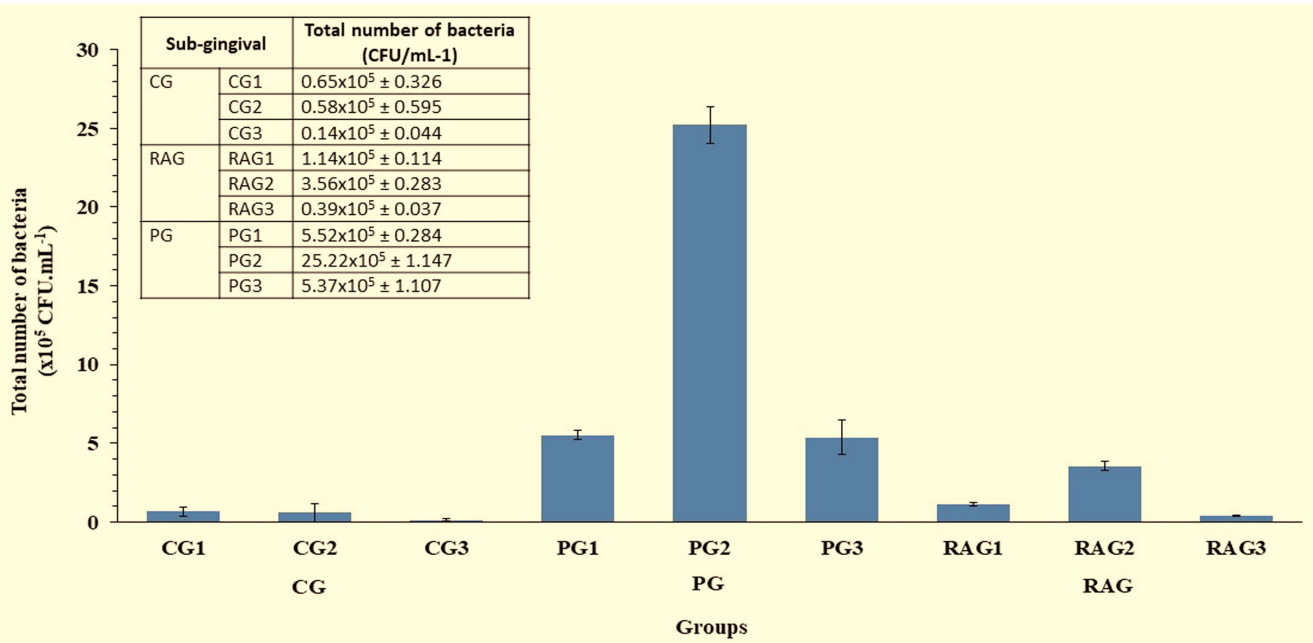

Figure 1. The number of bacteria varied in a stable concentration range of each group (CG $=\mathrm{Control}$ Sub-Gingival; $\mathbf{P G}=$ Periodontitis Sub-Gingival; RAG = RA Sub-Gingival)

All bacteria were found to have anaerobic growth character and dominantly living in the sample, thus they were able to grow in medium by incubating under anaerobic conditions. We found 8 isolates of bacteria from CG sample, 5 isolates of bacteria from PG sample and 10 isolates of bacteria from RAG sample. The bacterial diversity in RAG sample is higher than others so this result showed that microbial abnormalities (Table 1).

Table 1. Morphological characters of bacterial isolates were found at sub-gingival fluids control, RA and periodontitis.

\begin{tabular}{|c|c|c|c|c|c|c|c|c|}
\hline \multicolumn{2}{|c|}{ Isolates } & \multirow{2}{*}{$\begin{array}{c}\text { Shape } \\
\text { Round }\end{array}$} & \multirow{2}{*}{$\begin{array}{l}\text { Config. } \\
\text { Spread }\end{array}$} & \multirow{2}{*}{$\begin{array}{l}\text { Elevation } \\
\text { Pulvinat }\end{array}$} & \multirow{2}{*}{$\begin{array}{c}\text { Optic } \\
\text { Characteristics } \\
\text { Slant }\end{array}$} & \multirow{2}{*}{$\begin{array}{c}\text { Texture } \\
\text { Soft }\end{array}$} & \multirow{2}{*}{$\begin{array}{l}\text { Color } \\
\text { White }\end{array}$} & \multirow{2}{*}{$\begin{array}{l}\text { Side } \\
\text { Soft }\end{array}$} \\
\hline CG & 1 & & & & & & & \\
\hline & 2 & Round & Spread & Pulvinat & Slant & Soft & White & Soft \\
\hline & 3 & Absurd & Spread & Flat & Layered slant & Hard & Clear White & Soft \\
\hline & 4 & Round & Spread & Flat & Clear & Soft & Clear White & Soft \\
\hline & 5 & Absurd & Spread & Pulvinat & Shining diameter & Hard & Clear White & Jagged \\
\hline & 6 & Absurd & Spread & Flat & Clear & Hard & Clear White & Jagged \\
\hline & 7 & Irregular Stems & Spread & Convex & - & Soft & White & Jagged \\
\hline & 8 & Absurd & Spread & Flat & - & Hard & Clear White & Jagged \\
\hline \multirow[t]{5}{*}{ PG } & 1 & Round & Spread & Pulvinat & Slant & Soft & White & Soft \\
\hline & 2 & Round & Spread & Pulvinat & Slant & Soft & White & Soft \\
\hline & 3 & Round & Spread & Flat & White dot in the mid & Soft & White & Soft \\
\hline & 4 & Round & Spread & Flat & Clear & Soft & White & Soft \\
\hline & 5 & Absurd & Spread & Flat & Layered slant & Hard & Clear White & Soft \\
\hline \multirow[t]{10}{*}{ RAG } & 1 & Round & Spread & Pulvinat & Slant & Soft & White & Soft \\
\hline & 2 & Round & Spread & Pulvinat & Slant & Soft & White & Soft \\
\hline & 3 & Round & Spread & Flat & White dot in the mid & Soft & Clear White & Soft \\
\hline & 4 & Absurd & Spread & Flat & Layered slant & Hard & Clear White & Soft \\
\hline & 5 & Round & Spread & Flat & Dot in the mid & Soft & White & Soft \\
\hline & 6 & Round & Spread & Flat & Slant & Hard & Clear White & Soft \\
\hline & 7 & Irregular Stems & Spread & Flat & Clear & Soft & White & Soft \\
\hline & 8 & Round & Spread & Flat & Clear & Hard & Clear White & Soft \\
\hline & 9 & Round & Spread & Flat & Clear & Hard & White & Soft \\
\hline & 10 & Round & Spread & Flat & Clear & Hard & Clear White & Jagged \\
\hline
\end{tabular}

CG =Control Sub-Gingival; PG = Periodontitis Sub-Gingival; RAG = RA Sub-Gingival. 


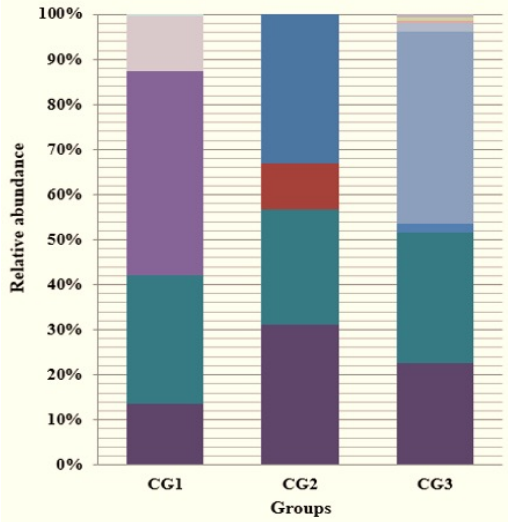

(A)

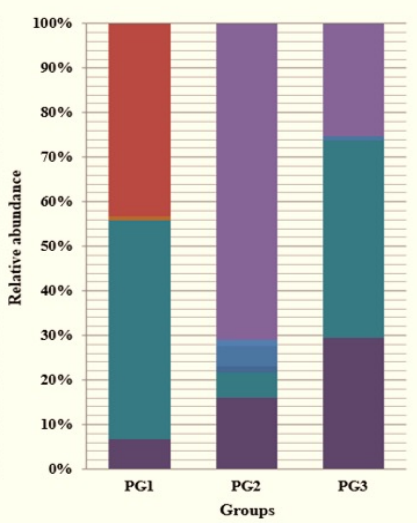

(B)

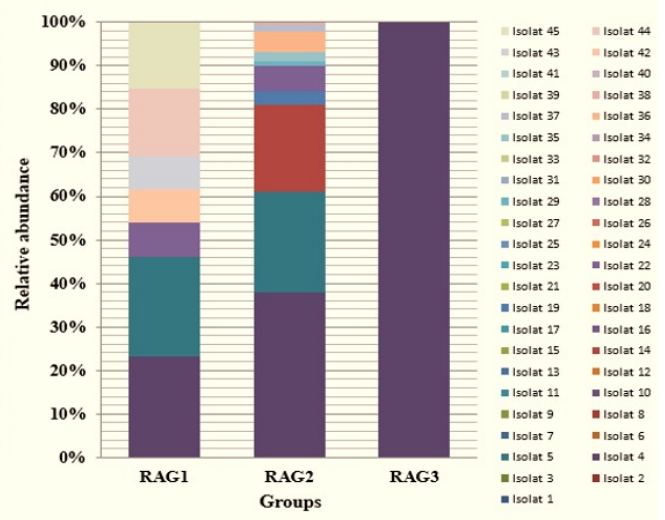

(c)

Figure 2. Relative abundance of bacteria at the sub-gingival of each group. A) Sub-gingival fluid control I, B) sub-gingival fluid periodontitis, C) sub-gingival fluid RA.

Based on the results, the Simpson index has a value $>0.61$ thus it can be concluded that the dominance of bacteria was high but the diversity of microbiota was at a low level of diversity.

\section{Discussion}

Microbiota is known to affect the body's immunity and metabolism. While microbiota abnormalities occurs (dysbiosis), it will increase the risk of infection [9,17]. Infection by microbiota will cause the appearance of inflammatory reactions that have an impact on changes in gene activity and metabolic disorders as well as the immune system that causes the emergence of disease [18]. These diseases include stomach infection, intestinal tissue damage, type $1 \mathrm{DM}$ [19], multiple sclerosis [20], and autism [21] as well as RA [8]. RA is associated with periodontitis due to the changes in the oral microbiota consortium, including Aggregatibacter sp, Prevotella intermedia, Tannerella forsythia, Fusobacterium nucleatum, Peptostreptococcus micros, and Porphyromonas gingivalis [22].

Furthermore, oral bacterial composition can play an important role in the oral environment associated with systemic and metabolic diseases [11]. The sub-gingival pathogenic bacteria in periodontitis, Porphyromonas gingivalis, can influence the development of RA disease due to able to express peptidyl arginine deiminase (PAD) associated with IgA ACPA [10]. The composition of bacterial diversity and the number of bacteria can determine the development of RA that can be identified by faecal analysis [23].

This result showed that the occurrence of microbiota abnormalities. The condition of microbiota abnormalities can lead to the inhibition mechanism of the other bacteria growth; hence it often raises the dominance of the certain microbiota growth that have an impact on the decline of microbiota population. Bacterial dominance, such as an increase in bacteria with a filamentous structure, is associated with the development of Th17 dependent cells that direct the appearance of arthritis in mouse models [24].

All bacteria were found to have anaerobic growth character and dominantly living in the sample; thus, they were able to grow in the medium by incubating under anaerobic conditions. Generally, the dominant bacteria that was found were anaerobic and facultative anaerobic bacteria belonging to the group of Firmicutes, Bacteroides, Proteobacteria, Verrucomicrobia and Actinobacteria [25]. An abundance of 4 and 5 were found in all three groups with different colonies. This result showed that the bacteria can grow and use the nutrients in the sub-gingival fluid, which is a natural micro-flora in the area. Bacterial analysis of sub-gingival fluids can be used to characterize metabolic functions related to microbiota [26]. There were 13 bacterial in the control 
group, while 8 bacterial were found in the periodontitis group and 14 bacterial were found in the RA group. The number of bacterial in periodontitis was less and dominant compared to the control group, while RA patients had greater bacterial abundance and diversity than the control group and periodontitis. It is suspected that some pathogenic bacteria appear in patients with periodontitis and RA, due to microbiota abnormalities in the intestine that affect the development of the disease.

The microbiota composition profile in control was different from the composition of the microbiota in periodontitis and RA patients. However, in general bacterial isolate 4, 5, and 22 were found in all three groups as natural micro-flora. RA patients showed abundant bacterial loss found in the sub-gingival fluid of the control group. However, new bacterial isolate found in the RA group that were not found in the control group were 14,35, and 36, which had high abundance. There was also found abundant bacteria loss in the control group on periodontitis patients.

In contrast, new bacterial isolates were found in the periodontitis group that was not found in the control group. It was abundant for isolate 14. Isolate 14 was also found to be abundant in RA disease. We suspected this bacterial was a pathogenic bacteria that due to dysbiosis and was related to the development of the disease because it was not found in the control group. The discovery of this bacteria in RA patients who did not suffer from periodontitis was thought to be a marker for the development of RA disease.

DNA of bacterial isolates have a low concentration and sterilization that was still low. Total DNA can be known for its sterilization by comparing the absorbance values of DNA samples at wavelength A260 / A280. The bacterial DNA has purity between 1.5-1.82. This value indicated that some of the bacterial DNA obtained was still not pure. According to previous study, the A260 / A280 ratio, which ranged from 1.8 to 2.0 in DNA samples, indicated that the DNA sample was pure [5].

\section{Conclusion}

Sub-gingival fluid microbiota composition profiles in patients with periodontitis and rheumatoid arthritis were found to have differences in diversity and total concentration of microbiota compositions. Bacterial isolate 4, 5 and 22 are natural micro-flora in sub-gingival fluid. However, isolate 14 with abundant amounts of bacteria were found in the patients suspected of causing dysbiosis. Hence, it affects the development of RA disease. The Simpson index has a value $>0.61$ with high bacterial dominance, but the diversity of microbiota is at a low level of diversity.

\section{Authors' Contributions}

$\begin{array}{lll}\text { VS } & \text { (D) O000-0002-9408-4932 } & \text { Methodology, Resources and Writing-Original Draft Preparation. } \\ \text { ES } & \text { (D) } 0000-0002-0748-4242 & \text { Conceptualization, Visualization, Investigation and Writing-Review and Editing. } \\ \text { MM } & \text { (D) 0000-0002-3994-9702 } & \text { Investigation and Formal Analysis. } \\ \text { NK } & \text { (D) } 0000-0003-4497-9487 & \text { Resources and Writing-Review and Editing. } \\ \text { All authors declare that they contributed to critical review of intellectual content and approval of the final version to be } \\ \text { published. }\end{array}$

\section{Financial Support}

Institute of Research and Community Services (LPPM), Brawijaya University (Grant No. 696. 101/UN10.C10/PN/2019).

\section{Conflict of Interest}

The authors declare no conflicts of interest. 


\section{References}

[1] Gibofsky A. Epidemiology, pathophysiology, and diagnosis of rheumatoid arthritis: a synopsis. Am J Manag Care 2014; 20 (7 Suppl):S128-35.

[2] Pinat LMA, Setijanto D, Bramantoro T. The correlation between mother's knowledge and parenting toward childhood caries in the remote area. J Int Dent Med Res 2017; 10(3):905-908.

[3] Wilsdon TD, Hill CL. Managing the drug treatment of rheumatoid arthritis. Aust Prescr 2017; 40(2):51-58. https://doi.org/10.18773/austprescr.2017.012

[4] Rahmawati DS, Indrawati R, Roestamadji RI, Setiawatie EM, Yuliati A, Bramantoro T. Osteogenic ability of combined hematopoetic stem cell, hydroxyapatite graft and platelet rich fibrin on rats (Rattus novergicus). J Krishna Inst Med Sci Univ 2017; 6(4):88-95.

[5] Fatchiyah F, Setiawan B, Suharjono S, Noor Z. The anti-osteoporosis effects of CSN1S2 protein of goat milk and yoghurt on a complete Freund's adjuvant-induced rheumatoid arthritis model in rats. Biomarkers Genomic Med 2015; 7(4):139-46. https://doi.org/10.1016/j.bgm.2015.10.001

[6] Ridwan RD, Tantiana T, Setijanto D, Kusuma AK, Putranto AF. The ability of electrolyzed reduced water to act as an antioxidant and anti-inflammatory agent in chronic periodontitis wistar rats (rattus novergicus). Kafkas Univ Vet Fak Derg 2019; 25(4):539-44. https://doi.org/10.9775/kvfd.2018.21284

[7] Scher JU, Ubeda C, Equinda M, Khanin R, Buischi Y, Viale A, et al. Periodontal disease and the oral microbiota in new-onset rheumatoid arthritis. Arthritis Rheum 2012; 64(10):3083-94. https://doi.org/10.1002/art.34539

[8] Zhang X, Zhang D, Jia H, Feng Q, Wang D, Liang D, et al. The oral and gut microbiomes are perturbed in rheumatoid arthritis and partly normalized after treatment. Nat Med 2015; 21(8):895-905. https://doi.org/10.1038/nm.3914

[9] Dietert R, Dietert J. The microbiome and sustainable healthcare. Healthcare 2015; 3(1):100-29. https://doi.org/10.3390/healthcare3010100

[10] Wegner N, Wait R, Sroka A, Eick S, Nguyen KA, Lundberg K, et al. Peptidylarginine deiminase from Porphyromonas gingivalis citrullinates human fibrinogen and $\alpha$-enolase: implications for autoimmunity in rheumatoid arthritis. Arthritis Rheum 2010; 62(9):2662-72. https://doi.org/10.1002/art.27552

[11] Schulz S, Porsch M, Grosse I, Hoffmann K, Schaller HG, Stefan R. Comparison of the oral microbiome of patients with generalized aggressive periodontitis and periodontitis-free subjects. Arch Oral Biol 2019; 99:169-76. https://doi.org/10.1016/j.archoralbio.2019.01.015

[12] Ambrosio N, Marín MJ, Laguna E, Herrera D, Sanz M, Figuero E. Detection and quantification of Porphyromonas gingivalis and Aggregatibacter actinomycetemcomitans in bacteremia induced by interdental brushing in periodontally healthy and periodontitis patients. Arch Oral Biol 2019; 98:213-19. https://doi.org/10.1016/j.archoralbio.2018.11.025

[13] Usami M, Miyoshi M, Kanbara Y, Aoyama M, Sakaki H, Shuno K, et al. Analysis of fecal microbiota, organic acids and plasma lipids in hepatic cancer patients with or without liver cirrhosis. Clin Nutr 2013; 32(3):444-51. https://doi.org/10.1016/j.clnu.2012.09.010

[14] Yusuf F, Ilyas S, Damanik HAR, Fatchiyah F. Microbiota composition, HSP70 and caspase-3 expression as marker for colorectal cancer patients in Aceh, Indonesia. Acta Med Indones 2016; 48(4):289-99.

[15] Guinness P, Walpole B. Environmental Systems and Societies for the IB Diploma Coursebook. 2nd ed. Cambridge: Cambridge University Press; 2015.

[16] Vural HC, Ozgun D. An improving DNA isolation method for identification of anaerobic bacteria in human colostrum and faeces samples. J Med Genet Genomics 2011; 3(5):95-100.

[17] Lee YK, Mazmanian SK. Has the microbiota played a critical role in the evolution of the adaptive immune system? Science 2010; 330(6012):1768-73. https://doi.org/10.1126/science.1195568

[18] Lynch SV, Pedersen O. The human intestinal microbiome in health and disease. N Engl J Med 2016; 375(24):2369-79. https://doi.org/10.1056/NEJMra 1600266

[19] Needell JC, Zipris D. The role of the intestinal microbiome in type 1 diabetes pathogenesis. Curr Diab Rep 2016; 16(10):89. https://doi.org/10.1007/s11892-016-0781-z

[20] Miyake S, Kim S, Suda W, Oshima K, Nakamura M, Matsuoda T, et al. Dysbiosis in the gut microbiota of patients with multiple sclerosis, with a striking depletion of species belonging to Clostridia XIVa and IV clusters. PLoS One 2015; 10(9):e0137429. https://doi.org/10.1371/journal.pone.0137429

[21] Sharon G, Sampson TR, Geschwind DH, Mazmanian S. The central nervous system and the gut microbiome. Cell 2016; 167(4):915-32. https://doi.org/10.1016/j.cell.2016.10.027

[22] Abdullah SN, Farmer EA, Spargo L, Logan R, Gully N. Porphyromonas gingivalis peptidylarginine deiminase substrate specificity. Anaerobe 2013; 23:102-8. https://doi.org/10.1016/j.anaerobe.2013.07.001

[23] Maeda Y, Kurakawa T, Umemoto E, Motooka D, Ito Y, Gotoh K, et al. Dysbiosis contributes to arthritis development via activation of autoreactive $\mathrm{T}$ Cells in the intestine. Arthritis Rheumatol 2016; 68(11):2646-61. https://doi.org/10.1002/art.39783 
[24] Wu HJ, Ivanov II, Darce J, Hattori K, Shima T, Umesaki Y, et al. Gut-residing segmented filamentous bacteria drive autoimmune arthritis via $\mathrm{T}$ helper 17 cells. Immunity 2010; 32(6):815-27. https://doi.org/10.1016/j.immuni.2010.06.001

[25] Donaldson GP, Lee SM, Mazmanian SK. Gut biogeography of the bacterial microbiota. Nat Rev Microbiol 2016; 14(1):20-32. https://doi.org/10.1038/nrmicro3552

[26] Matysik S, Roy CIL, Liebisch G, Claus SP. Metabolomics of fecal samples: a practical consideration. Trends Food Sci Technol 2016; 57:244-55. https://doi.org/10.1016/j.tifs.2016.05.011 